\title{
Self-Efficacy of Medical Students in Two Schools with Different Education Methodologies (Problem-Basead Learning versus Traditional)
}

\author{
Autoeficácia de Estudantes de Medicina em Duas Escolas com \\ Metodologias de Ensino Diferentes (Aprendizado Baseado em \\ Problemas versus Tradicional)
}

\author{
Janaína Maciel Lopes ${ }^{1}$ (iD \\ João Gabriel Franco Castro ${ }^{\mathrm{I}}$ (D) \\ José Maria Peixoto ${ }^{\mathrm{I}}$ (D) \\ Eliane Perlatto Moura ${ }^{\mathrm{I}}$ (D)
}

\section{KEYWORDS}

- Self-efficacy.

- Medical Education.

- Medical Students.

- Curriculum

Introduction: Academic self-efficacy refers to the student's belief in their ability to organize and perform actions regarding academic activities and demands. In this context, self-efficacy has received great importance in the literature, both for the relevance and the predictive power of the events in the school setting. Students with higher levels of self-efficacy are more likely to succeed in their interventions, as they can more easily test and use their skills. Objective: To evaluate the academic self-efficacy of students in the $4^{\text {th }}$ year of medical school and its correlation with the teaching method (PBL x traditional). Method: This is a cross-sectional and quantitative study carried in two medical schools: one with PBL methodology and another with traditional methodology. A total of $1474^{\text {th }}$-year medical students participated in this study, who were divided in two groups, 73 from the school using the PBL methodology and 74 from the school with the traditional methodology. Data collection was carried out by filling out a self-answered questionnaire, containing questions on sociodemographic information and general health aspects, in addition to the Self-efficacy Scale in Higher Education. Result: Students from the school using the PBL methodology had a overall higher mean sum of the highest score $(p<0.01)$ and higher mean score in each domain of the self-efficacy scale when compared to the school using the traditional methodology. The variables female gender, older age, living alone, not using medication for chronic disease and having an extracurricular activity had a positive influence on the mean self-efficacy score in the different scale domains. Conclusion: The $4^{\text {th }}$-year medical students of the assessed institutions showed moderate to strong selfefficacy. Students from PBL school had higher self-efficacy scores than those using the traditional methodology. These results may indicate that the active learning methodology such as the PBL curriculum may be related to a higher degree of academic self-efficacy. Further studies are required to understand the influence of the curricular model on medical students' academic self-efficacy. 


\section{PALAVRAS-CHAVE}

- Autoeficácia.

- Educação Médica.

- Estudantes de Medicina.

- Currículo.

\section{RESUMO}

Introdução: A autoeficácia acadêmica refere-se à crença do estudante em sua capacidade de organizar e executar ações relacionadas às atividades e exigências acadêmicas. Nesse contexto, a autoeficácia tem recebido grande destaque da literatura tanto pela relevância quanto pelo poder preditivo dos acontecimentos no âmbito escolar. Estudantes com maiores níveis de autoeficácia têm maiores probabilidades de ser bem-sucedidos nas suas intervenções, pois conseguem mais facilmente testar e utilizar as suas competências. O objetivo deste estudo foi avaliar a autoeficácia acadêmica de estudantes do quarto ano de Medicina em duas escolas com metodologia de ensino diferentes: aprendizado baseado em problemas (ABP) versus tradicional. Método: Tratase de estudo transversal e quantitativo que foi conduzido em duas escolas de Medicina: uma com metodologia ABP e outra com metodologia tradicional. Participaram deste estudo 147 estudantes de Medicina do quarto ano divididos em dois grupos: 73 da escola com metodologia ABP e 74 da escola com metodologia tradicional. A coleta de dados foi realizada pelo preenchimento de questionário autorrespondido, contendo perguntas de avaliação sociodemográfica e aspectos gerais de saúde, além da Escala de Autoeficácia na Formação Superior. Resultados: Os alunos da escola com metodologia ABP apresentaram média geral do somatório do escore maior $(p<0,01)$ e média do escore maior em cada domínio da escala de autoeficácia quando comparados com a escola de metodologia tradicional. As variáveis sexo feminino, ser mais velho, morar sozinho, não usar medicamento para doença crônica e exercer atividade extracurricular apresentaram influência positiva na média de escore de autoeficácia nos diferentes domínios da escala. Conclusões: Os estudantes de Medicina do quarto ano de ambas as instituições analisadas apresentaram autoeficácia de moderada a forte. Os estudantes da escola do ABP apresentaram escores de autoeficácia maiores em relação aos da escola com metodologia tradicional. Esses resultados indicam que o uso de metodologia ativa de ensino, como a do ABP, pode se relacionar a um maior grau de autoeficácia acadêmica. Mais estudos são necessários para uma melhor compreensão da influência do modelo curricular adotado na autoeficácia acadêmica, em estudantes de Medicina.

Received on $10 / 16 / 19$

Accepted on $1 / 9 / 20$

\section{INTRODUCTION}

Self-efficacy is defined as the "judgment the subject has about their abilities to organize and execute necessary actions to achieve certain types of performances"1. Self-efficacy is based on the idea of personal competence, because it is this notion that allows subjects to estimate the possibility of performing tasks and achieving the desired results, leading them to create expectations for their accomplishment, helping determining choices regarding the activities and means, as well as the necessary efforts, persistence, cognitive patterns and emotional reactions to face the challenges $^{1,2,3}$.The self-efficacy belief is developed from four sources: (1) personal performance, based on results of the own experiences that serve as capacity indicators; (2) vicarious experience, which refers to the human being's capacity to learn from the experiences of other people, working through the transmission of skills and the comparison of the obtained results; (3) social persuasion, when the social environment promotes the perception that the person has the capacity to solve problems; and (4) physical and emotional state, from which the person infers their capacity, strength and vulnerability in the face of challenges. In this proposition, self-efficacy does not guarantee the necessary skill to carry out an activity, as it does not compensate for the lack of the minimum necessary skills to perform the tasks, but it provides the perception of the capacity to initiate and maintain the process for its accomplishment ${ }^{1,5}$.

Considering the domain of academic self-efficacy, the processes of self-perceptions and individual beliefs favor the student to transform psychological competencies into school performance skills ${ }^{6}$. Thus, academic self-efficacy refers to the student's belief in their ability to organize and execute actions related to academic activities ${ }^{7,8}$. The relevance of this construct lies in the possibility of predicting students' actions based on the beliefs they have in their capacities, rather than what they are really capable of doing'. Students with a high belief in their academic efficacy are more available for study and are more persistent in the face of academic challenges ${ }^{7,10}$. Students' self-efficacy, along with other beliefs and attitudes, is related to several aspects of learning, such as: performance, outcomes, the magnitude of motivation; the value attributed to a certain learning task; the control of perceived learning, involvement with the course; cooperation with colleagues; critical thinking and knowledge ${ }^{11,12,13,14}$.

According to Guerreiro-Casanova and Polydoro ${ }^{15}$, self-efficacy is an important factor in the integration of students into higher education. Students with higher levels of self-efficacy are more likely to be successful in their interventions, as they are able to test and use their skills more easily, since they are more available to accept challenges and recover more quickly from failure. It is not the amount of skills that an individual has that will guarantee the accomplishment of the task, but the belief and aptitude to mobilize this skill in the task accomplishment, converting both (belief and skill) into an important personal influence mechanism ${ }^{4,16,17}$.

Particularly in medical school, the students need to develop skills aimed at problem-solving, decision-making and clinical judgment, and since medical knowledge is constantly evolving, it is essential that students develop self-regulated learning skills (SRLS) to remain updated throughout life ${ }^{18}$. The skills described above are indicative of their motivation development, with self-efficacy being one of the most often studied self-motivation constructs ${ }^{17,19}$.

REVISTA BRASILEIRA DE EDUCAÇÃO MÉDICA

2 44 (2) : e047; 2020 
A teaching methodology aimed at facilitating the development of SRLS is the problem-based learning (PBL), which helps students to develop effective problem-solving skills and to become active participants in their own learning, enabling them to build knowledge ${ }^{18}$. In PBL, students learn contents, strategies, develop self-directed learning skills by collaboratively solving problems and reflecting on their experiences, being encouraged to take responsibility for their own learning; it is, therefore, an active teaching methodology ${ }^{18}$. According to Bandura ${ }^{1}$, active teaching methodologies have an effect on self-efficacy factors: personal experiences, vicarious experiences, social persuasion and physiological indicators. Activities based on problem solving, simulations and project development can lead to positive personal experiences and an increase in the personal belief in one's ability to perform a certain task. In this sense, active methodologies enable students to be actively involved in their own training process. In a study by Reeve ${ }^{20}$, the author emphasized that students who perceived themselves as autonomous in their academic interactions showed positive results in relation to motivation and skill perception.

However, while most studies suggest that PBL promotes greater SRLS in relation to the traditional teaching programs, some have reported negative results ${ }^{18}$. The question whether the type of curricular model adopted by the medical school would be capable of influencing the development of students' self-efficacy motivated the development of this study, which aimed to evaluate the academic self-efficacy of $4^{\text {th }}$-year medical students in two institutions with different teaching methodologies (PBL and traditional), located in the city of Belo Horizonte, state of Minas Gerais, Brazil.

\section{METHODOLOGY}

Study and participants

A cross-sectional and quantitative study was performed using a self-administered questionnaire to assess the self-efficacy of medical students. Fourth-year medical students from two institutions located in Belo Horizonte, Minas Gerais, Brazil were enrolled, which adopt different teaching methodologies: the first institution, herein called Institution A, uses the PBL methodology, and the second, Institution $\mathrm{B}$, uses a teaching method characterized as traditional. The $4^{\text {th }}$ year was chosen because it is a period of transition in the medical course, characterized by a greater participation in practical activities of the professionalizing phase and common to both institutions. The students were selected for convenience, and the invitation was made by the researchers in the classrooms, at a time that was predetermined with the teacher, followed by the completion of the questionnaire by the students who agreed to participate and signed the free and informed consent form.

\section{Instruments}

The research instrument used for data collection contained 52 questions, 18 of which were socio-demographic assessment questions created by the researchers, and the Self-Efficacy Scale in Higher Education, containing 34 questions, built and validated by Polydoro and Guerreiro-Casanova ${ }^{21}$.

- Sociodemographic questionnaire: The analyzed variables were: name, gender, age, family income, having a first-degree relative that was a physician, marital status, living alone or with family, having paid work, number of weekly hours worked, having any health problems, antidepressant medication use, chronic medication use, being a smoker, having attended the entire course at the same institution, being regularly enrolled in the course, having an extracurricular activity and participating in extracurricular activities.

- Self-efficacy Scale in Higher Education: This is a questionnaire with 34 questions, answered on a Likert-type scale with 10 points, divided into 5 dimensions. Of these 34 questions that comprise the questionnaire, 9 evaluate academic self-efficacy (perceived confidence in one's capacity to learn, demonstrate and apply knowledge); 7 evaluate self-efficacy in training regulation (perceived confidence in the capacity to set goals, make choices, plan and self-regulate their actions in the process of training and career development); 7 evaluate self-efficacy in proactive actions (perceived confidence in the capacity to take advantage of training opportunities, update knowledge and promote institutional improvements); 7 evaluate self-efficacy in social interactions (perceived confidence in the capacity to have a relationship with colleagues and teachers for academic and social purposes); and 4 evaluate self-efficacy in academic management (perceived confidence in the capacity to get involved, plan and meet deadlines in relation to academic activities). According to Polydoro and Guerreiro-Casanova ${ }^{21}$, it is possible to grade self-efficacy into weak (values up to 5.9), moderate (values between 6 to 7.9) and strong (values between 8 to 10 ). The internal consistency of the scale is 0.94 . It varies between 0.80 to 0.81 in the dimensions and the total explained variance is 56.68 , which shows the adequacy of the instrument ${ }^{21}$.

- Academic performance: Academic performance was measured by the overall mean obtained considering all the subjects that were taken by the students up to the moment the study was carried out and which were made available by the institutions.

\section{Data analysis}

The mean of the sum of the scores of the 34 questions was used to evaluate the overall self-efficacy in each institution (total score), and the mean of the scores of the questions related to each of the five dimensions, to evaluate the students' self-efficacy in each instrument domain. Descriptive statistics were performed for data analysis, and a univariate analysis was carried out using Student's $t$ tests and/or Analysis of Variance (ANOVA), chi-square and Pearson's correlation test, aiming at preselecting the variables of interest for the multivariate analysis, where the Multiple Linear Regression analysis was applied. The level of significance was set at $5 \%(\mathrm{p}<0.05)$. The program SPSS 14.0 for Windows (Statistical Software) was used for data analysis.

Ethical Considerations: The project was sent to the Research Ethics Committee of Universidade José do Rosário Vellano, and received a favorable Opinion, under the CAAE number 84589418.5.0000.5143.

\section{RESULTS}

Sociodemographic profile

The study included 147 medical students attending the $4^{\text {th }}$ year of undergraduate school ( $49 \%$ of the total students enrolled in both

REVISTA BRASILEIRA DE EDUCAÇÃo MÉDICA

3 44 (2) : e047; 2020 
institutions), with 73 students from Institution A and 74 students from Institution B. This sample represented $44.2 \%$ of the students enrolled in the $4^{\text {th }}$ year at Institution A and $55.2 \%$ of students enrolled in the $4^{\text {th }}$ year at Institution B. Overall, the participants were characterized by: being female (67.1\% at Institution A and 73\% at Institution B); aged between 19 and 30 years, family income higher than $\mathrm{R} \$ 10,000.00$; not having a first-degree relative that was a physician, being single, not having paid work, not reporting any health problems; not using any medication, were nonsmokers, had not changed educational institutions during the medical course; were regular enrolled in the course and were engaged in some extracurricular activity. When comparing the characteristics of students from the two institutions, a significant difference was observed in relation to the following variables: age, having a first-degree relative that was a physician and living alone or with family, with a higher percentage of students from Institution A having an average older age, no first-degree relative that was a physician and living alone. There was no significant difference between the groups in relation to the other assessed variables.

\section{Analysis of the Self-efficacy Scale in Higher Education}

The self-efficacy of students was evaluated in each institution considering the overall mean of the obtained scores and it was observed that the students from Institution A (PBL) had a strong perceived selfefficacy when compared with the students from Institution B (traditional), whose self-efficacy was moderate (Table 1). Self-efficacy was also assessed in the five domains of the self-efficacy scale and it was observed that students from Institution A had higher values in all domains of the selfefficacy scale, with the exception of the self-efficacy domain in social interaction, which showed no difference between the groups. (Table 2).

\section{Table 1}

$\begin{array}{ccc}\text { Table } 1 & \\ \text { Perceived self-efficacy of } 4 \text { 4th-year medical students from Institution } \\ & \text { A and Institution B } & \mathbf{p}^{*} \\ \text { Institution } & \text { Mean } & \mathbf{0 . 0 0 1} \\ \text { Institution A } & 8.1 & \\ \text { Institution B } & 7.5 & \end{array}$

Database: 147 students

Note: the probability of significance refers to Student's $t$ test $\left(^{*}\right)$,

Source: Elaborate by the authors

\begin{tabular}{|cccc}
\hline \multicolumn{4}{c}{ Table 2} \\
Comparative analysis between institutions & regarding the self-efficacy \\
& scale domains & \\
\hline Self-efficacy scale domain & Institution A & Institution B & p \\
\hline Academic & $8.5 \pm 1.0$ & $7.8 \pm 1.4$ & $<0.001$ \\
\hline Training regulation & $8.0 \pm 1.3$ & $7.2 \pm 1.6$ & 0.002 \\
\hline Proactive Actions & $7.3 \pm 1.5$ & $6.5 \pm 1.8$ & 0.004 \\
\hline Social interaction & $8.4 \pm 1.6$ & $8.1 \pm 1.4$ & 0.221 \\
\hline Academic Management & $8.8 \pm 1.1$ & $8.3 \pm 1.6$ & 0.033 \\
\hline
\end{tabular}

Database: 147 students

Note: the probability of significance refers to Student's $t$ test $\left(^{*}\right)$,

Source: Elaborate by the authors
Comparative analysis was performed to identify possible associations between sociodemographic variables and the levels of academic selfefficacy demonstrated by the students. In this study, in general, female students had superior results in the academic self-efficacy and academic management domains. A weak positive correlation was identified between age and the self-efficacy domain in training regulation. Older students showed greater self-efficacy when compared to younger students. Students who lived alone showed significantly higher results in relation to the self-efficacy scale in proactive actions. Significantly higher results in the domains of self-efficacy in social interaction and academic management were observed in the group of students who did not use medication for chronic diseases. Students who had extracurricular activities showed greater academic self-efficacy. And there was a significant, positive and weak correlation between the student's academic performance and selfefficacy in academic management.

It is noteworthy that the studied groups were homogeneous in relation to sociodemographic characteristics, except in relation to the variables: age and living alone. Therefore, univariate analyses were carried out of the influence of these variables on the self-efficacy of $4^{\text {th }}$-year medical students in each institution and there were no significant differences in the academic self-efficacy scores between the two institutions.

\section{DISCUSSION}

This study aimed to compare the self-efficacy of $4 \mathrm{t}^{\mathrm{h}}$-year medical students from educational institutions that adopt different curricular models (PBL and traditional), and to correlate the self-efficacy scores with the sociodemographic factors of the participants. Our initial hypothesis was that students from the educational institution that uses the PBL methodology would show greater academic self-efficacy. Our results confirmed this hypothesis.

This study demonstrated that medical students from both institutions showed self-efficacy that varied between moderate and strong, and students from the institution using the PBL methodology had higher scores in academic self-efficacy. This fact was observed when evaluating the overall self-efficacy of students from both institutions.

These results may be related to the structure of PBL, which is based on learning where the student has an active role. PBL enhances the development of clinical reasoning, favors the development of self-directed study skills, improving the way learning occurs, favoring motivation and self-regulation ${ }^{15,22}$. According to Polydoro and Azzi ${ }^{23}$, self-regulation is associated with the judgment of one's capacity and the use of cognitive and metacognitive strategies that lead to self-reinforcement. Thus, selfregulation influences the belief in self-efficacy by providing information about performance, effort and time spent in carrying out the activity, participating in its construction ${ }^{24}$. Another important aspect of the PBL methodology to be highlighted is the emphasis on feedback, which encourages self-assessment and reflection on one's conduct and that of the other members of the group. According to Bandura ${ }^{25}$, the controlled action, with instructive feedback, can be used as a vehicle to convert concepts into proficient performances. The feedback that accompanies the actions provides the necessary information to detect and correct differences between conceptions and actions. Therefore, the behavior is modified based on comparative information, so that the desired skills are mastered, enhancing self-efficacy. 
In this study, sociodemographic factors correlated significantly with the different domains of the self-efficacy scale. Regarding the academic selfefficacy, which assesses the students' perceived confidence in their ability to learn, demonstrate and apply the course content, a positive correlation was observed with the fact that the student performed extracurricular activities. These results were expected, since, according to Vieira et al. ${ }^{26}$ the importance of extracurricular activities is reflected in the fact that they are capable of scoping professional training beyond what is proposed by the educational actions found in a curricular structure, providing greater freedom of choice, on the part of the students, about the activities to be developed. According to Santos $^{27}$ and Fior and Mercuri ${ }^{28}$, extracurricular activities have the potential to stimulate the development of the university student's characteristics in five main domains: (1) academic knowledge and skills, (2) cognitive complexity, (3) practical competence, (4) interpersonal competence and (5) humanitarianism. According to Pascarella and Terenzini ${ }^{29}$, the benefits of non-mandatory experiences are reflected in several aspects, which can help the student's development in several areas, leading to greater satisfaction with the course, improvement of leadership skills, easier interpersonal relationships and development of altruistic values.

Within the scope of self-efficacy in the training regulation, there was a positive, but weak, correlation with age, where older students showed superior results. This may be due to the greater life experience, leading them to be more efficient in self-regulating their own learning. The data recorded by the research were consistent with those observed by Dias and Azevedo $^{30}$ and Oliveira and Simões ${ }^{31}$ who observed that older students, who have greater educational experience and knowledge of their own limitations, showed greater self-efficacy when compared to younger ones.

In the domain of self-efficacy in proactive actions, living alone had a positive influence. Based on the concepts of self-efficacy, previously reported in this study, where Bandura ${ }^{32}$ and Martins ${ }^{33}$ report that the experiences lived during their insertion into social systems lead the individual to a realistic perception of their weaknesses and potentials, one can infer that the fact of living alone makes the student acquire greater knowledge of their limitations and ability to solve problems, which positively impacts their proactive actions.

The use of medication for chronic diseases had a negative correlation with self-efficacy in social interaction and academic management. This correlation should be better investigated; however, these findings are important, since, according to Ramos ${ }^{34}$, investigating the reality experienced by students, aiming to understand it, is essential to act in stressful situations that can affect their health and interfere with their expectations, resulting in academic failure and decreased self-efficacy.

Regarding gender, the data found in the literature are controversial. Turan, Demirel and Sayek ${ }^{35}$, when studying the academic self-efficacy of medical students from schools with different curricular models (PBL and traditional) in Turkey, found no differences between the genders. However, in another study carried out in Turkey, by Demirören, Turan and Öztuna ${ }^{18}$ with medical students from a school using PBL methodology, it was observed that women had higher scores in relation to planning and setting goals. Our findings are in line with what was observed by these authors, since in the self-efficacy domain in academic management, related to perceived confidence in the capacity to get involved, plan and meet deadlines related to academic activities, the women's mean scores were higher. Studies report that women have greater self-confidence in the capacity to organize, plan and structure strategies aimed at improving their learning, being considered more responsible in relation to their study ${ }^{36,18}$.

Academic performance showed a positive correlation with selfefficacy in academic management. These results are in accordance with a report by Rodrigues and Barrera $^{37}$, which states that self-efficacy influences school performance and, at the same time, is influenced by it. Students with a high sense of self-efficacy tend to try harder, which ends up influencing the quality of results and, directly or indirectly, the acquisition of skills, thanks to persistence. According to Zimmerman ${ }^{6}$, the self-perception of efficacy stimulates the self-regulation process, with positive effects on academic performance.

\section{CONCLUSION}

In this study, $4^{\text {th }}$-year medical students from both analyzed institutions showed moderate to strong self-efficacy. Students at the PBL school had higher self-efficacy scores than those at the school with traditional methodology. These results may indicate that the use of active teaching methodology, such as that of the PBL model, may be related to a greater degree of academic self-efficacy. Thus, the results of this study, guided by the perspective of the Social Cognitive Theory, reinforce the role of the environment in the development of academic self-efficacy. However, these results must be analyzed with caution, since it is a cross-sectional study, carried out only among fourth-year undergraduate medical students and, therefore, cannot be representative of self-efficacy throughout the course. This study provides directions for future research. A study of students' self-efficacy using a longitudinal design could help to understand how selfefficacy evolves during the medical course, whether students at the end of graduation show greater development of this construct, which would favor the training of professionals with self-regulated study capacity, a relevant skill for learning throughout their professional life. New studies should be carried out aiming at a better understanding of what factors (among them the curricular model) are associated with the development of academic self-efficacy in medical students, to support actions that can have a positive impact on the student's academic performance and for the planning of curricular adjustments.

\section{REFERENCES}

1. Bandura A. Self-efficacy: the exercise of control. New York: Freman; 1997.

2. Bong M, Skaalvik EM. Academic self-concept and self-efficacy: how different are they really? Educ. psychol. rev. 2003;15(1):1-40.

3. Schunk DH, Ertmer PA. Self-regulation and academic learning: self-efficacy enhancing interventions. In: Boekaerts $M$, Pintrich PR, Zeidner M., editors. Handbook of self-regulation. San Diego: Academic Press; 2000. p. 631-49.

4. Pajares F, Olaz F. Teoria social cognitiva e autoeficácia: uma visão geral. In: Bandura A, Azzi RG, Polydoro S., editores. Teoria social cognitiva: conceitos básicos. Porto Alegre: Artmed; 2008. p. 97-114.

5. Bandura A. Social cognitive theory: an agentic perspective. Ann. rev. psychol. 2001;52(1):1-26.

6. Zimmerman BJ. Attaining self-regulation: A social-cognitive perspective. In: Boekaerts M., Pintrich P, Zeidner M., editors. Self-

\begin{tabular}{l|l}
\hline REVISTA BRASILEIRA DE EDUCAÇÃO MÉDICA \\
44 (2) : e047; 2020
\end{tabular} 
regulation: theory, research, and applications. Orlando: FL7 Academic Press; 2000. p. 13-39.

7. Joly MCRA, Prates EAR. Teaching and learning in information society: the importance of self-regulation and self-efficacy. In: Mendez-Villas A., editor. Education in technological world: communicating current and emerging research and technological efforts. Badajoz: Formatex; 2011. p. 448-56.

8. Bandura A. Perceived self-efficacy in cognitive development and functioning. Education Psychologist 1993;28 (2):117-48.

9. Joly MCRA, Serpa ALO, Borges L, Martins RMM. Autoeficácia acadêmica e autorregulação da aprendizagem: rede de relacionamento em bases online. Aval. psicol. 2016;15(1):73-82.

10. Pajares F. Self-efficacy beliefs in academic settings. Rev. educ. res. 1996;66(4):543-78.

11. Byer JL. The effects of college students' perceptions of teaching and learning on academic self-efficacy and course evaluations. 2001. [acesso em 20 mar 2018]. Disponível em: https://files.eric.ed.gov/ fulltext/ED460142.pdf.

12. Cole JS, Denzine GM. I'm not doing as well in this class as I'd like to: exploring achievement motivation and personality. Journal of College Reading and Learning 2004;34(2): 29-44.

13. Jakubowski TG, Dembo MH. The relationship of self-efficacy, identity style, and stage of change with academic self-regulation. Journal of College Reading and Learning 2004;35(1):7-24.

14. Azzi RG, Polydoro S. Autoeficácia em diferentes contextos. Campinas: Alínea; 2006.

15. Guerreiro-Casanova DC, Polydoro SAJ. Autoeficácioa na formação superior: percepções durante o primeiro ano de graduação. Psicol. ciênc. prof. 2011;31(1):50-65.

16. Bandura A, Cervone D. Differential engagement of self-reactive influences in cognitive motivation. Org. behave. hum. decis. process. 1986;38(1):92-113.

17. Bandura A. Self-efficacy determinants of anticipated fears and calamities. J. pers. soc. psychol. 1983;45(2):464-9.

18. Demirören M, Turan S, Öztuna D. Medical students' self-efficacy in problem-based learning and its relationship with self-regulated learning. Med. educ. online 2016;21:30049.

19. Buckley T, Gordon C. The effectiveness on high fidelity simulation on medical-surgical registered nurses' ability to recognize and respond to clinical emergencies. Nurse educ. today 2011;31(7):716-21.

20. Reeve J. Why teachers adopt a controlling motivating style toward students and how they can become more autonomy supportive. Educational Psychologist 2009;44(3):159-75.

21. Guerreiro-Casanova DC, Polydoro SA. Escala de Autoeficácia na Formação Superior: construção e estudo de validação. Aval. psicol. 2010;9(2):267-78.

22. Toledo Júnior AC de C, Ibiapina $C$ da $C$, Lopes SCF, Rodrigues ACP, Soares SMS. Aprendizagem baseada em problemas: uma nova referência para a construção do currículo médico. Educação Médica de Minas Gerais 2008;18(2):123-31.

23. Polydoro SAJ, Azzi, RG. Autorregulação da aprendizagem na perspectiva da teoria sociocognitiva: introduzindo modelos de investigação e intervenção. Psicol. educ. 2009;29:75-94.

24. Zimmerman BJ, Cleray TJ. Adolescents' development of personal agency. In: Pajares F, Urdant T., editors. Self-efficay beliefs of adolescents. Charlotte: Information Age Publishing; 2006. p. 45-69.

25. Bandura A. The evolution of social cognitive theory. In: Smith KG, Hitt MA. Great minds in management. Oxford: University Press; 2005. p. 9-35.

26. Vieira E, Barbieri C, Vilela D, Ianhez Júnior E, Tomé F, Woida F, et al. O que eles fazem depois da aula? As atividades extracurriculares dos alunos de ciências médicas da FMRP-USP. Medicina (Ribeirão Preto, Online) 2004;37(1/2):84-90.

27. Santos LTM dos. Vivências acadêmicas e rendimento escolar: estudo com alunos universitários do $1^{\circ}$ ano [dissertação]. Braga: Instituto de Educação e Psicologia da Universidade do Minho; 2000.

28. Fior CA. Mercuri E. Formação universitária: o impacto das atividades não obrigatórias. In: Mercuri E, Polydoro SAJ., organizadores. Estudante universitário: características e experiências de formação. Taubaté: Cabral Editora e Livraria Universitária; 2003. p. 241-47.

29. Pascarella ET, Terenzini PT. How college affects students: a third decade of research. 2nd ed. San Francisco: Jossey-Bass; 2005. v. 2.

30. Dias GF, Azevedo M. Desenvolvimento psicológico, atitudes em relação ao estudo e sucesso acadêmico. Fases on-line: factores de sucesso/insucesso do ensino superior. n 1 [acesso em 20 mar 2018]. Disponível em: https://www.ualg.pt/pt/OPQE/fases.

31. Oliveira AL, Simões A. Validação do questionário de autoeficácia para a aprendizagem autodirigida: sua relevância na facilitação da aprendizagem dos estudantes do ensino superior. Revista Portuguesa de Pedagogia 2001;35(1):171-90.

32. Bandura A. Self-efficacy: toward a unifying theory of behavioral change. Psychol. rev. 1977;84(2): 191-215.

33. Martins JCA, Baptista RCN, Coutinho VRD, Mazzo A, Rodrigues MA, Mendes IAC. Autoconfiança para intervenção em emergências: adaptação e validação cultural da self-confidence scale em estudantes de Enfermagem. Rev Latino Am Enfermagem. 2014;22(4): 554-61.

34. Ramos SIV. Motivação académica dos alunos de ensino superior. Psicologia.PT 2013;1-15.

35. Turan S, Demirel O, Sayek I. Metacognitive awareness and self regulated learning skills of medical students in different medical curricula. Med. teach. 2009;31:477-83.

36. Pajares F. Self-efficacy beliefs in academic contexts: an outline 2002 [acesso em 20 mar 2018]. Disponível em: http://www.emory.edu/ EDUCATION/mfp/efftalk.html.

37. Rodrigues LC, Barrera SD. Autoeficácia e desempenho escolar em alunos do ensino fundamental. Psicol. pesq. 2007;1(2):41-53.

\section{AUTHORS' CONTRIBUTION}

Janaina Lopes actively participated in the study design, data collection; discussion of results and the writing of the manuscript. João Castro actively participated in the study design and data collection. José Peixoto participated in the review and approval of the final version of the manuscript. Eliane Moura actively participated in the study design, data collection, discussion of results, writing of the manuscript, review and approval of the final version of the manuscript. 


\section{CONFLICTS OF INTEREST}

The authors declare no conflicts of interest.

ADDRESS FOR CORRESPONDENCE

Eliane Perlatto Moura

Universidade José do Rosário do Rosário Vellano, Rua Líbano, 66

Itapoã, Belo Horizonte, MG-Brasil. CEP: 31710-030

E-mail: elianeperlatto@gmail.com 